\title{
Accommodating stormwater storage structure in the veranda of shop building
}

\author{
Darrien Y.S. Mah ${ }^{1 *}$, Norazlina Bateni ${ }^{1}$, Rosmina A. Bustami ${ }^{1}$, Jethro H. Adam ${ }^{1}$ and Afdal H.M. \\ Salehe $^{2}$ \\ Faculty of Engineering, Universiti Malaysia Sarawak, 94300 Kota Samarahan, Sarawak, Malaysia ${ }^{1}$ \\ Director of Syarikat Haziq Jaya Pvt Ltd, Desa Ilmu, 94300 Kota Samarahan, Sarawak, Malaysia ${ }^{2}$
}

Received: 15-July-2021; Revised: 20-September-2021; Accepted: 22-September-2021

(C)2021 Darrien Y.S. Mah et al. This is an open access article distributed under the Creative Commons Attribution (CC BY) License, which permits unrestricted use, distribution, and reproduction in any medium, provided the original work is properly cited.

\begin{abstract}
This paper describes the investigation to place a water storage structure under the veranda of a shop building. A veranda is a commercial building feature in Southeast Asia with a narrow walkway about $3 \mathrm{~m}$ wide. Given the small space'slimited capability to hold rainwater from the building roof, a draining tank is, therefore, a more viable choice. Rainwaters flow in and out the tank simultaneously with an outlet control that enables water storage within. A modular-based stormwater storage system that could be assembled under the veranda was selected. Storm Water Management Model version 5.0 was used to model the system. The modular-based system's availability of field test data allowed calibration and verification exercises using the mentioned software and yielded $R$ Square values between 0.97-0.99. As such, the parameters of the system as a storage unit were applied in the modelling of the same system in the veranda. Two cases were presented. The water storage structure was modelled in a single shop lot and a partial commercial area with six units of shop lots and surrounding streets. Modelling the single shop lot with $60 \%$ of its roof directing waters to the water storage structure was predicted to reduce $25-30 \%$ of its peak values comparing the post-development hydrographs with and without the intervention. The partial commercial area modelling yielded only $0.4-10 \%$ prediction in its reduction, suggesting additional intervention was required.
\end{abstract}

\section{Keywords}

Flood adaptive, Sponge city, Stormwater detention, Sustainable development, SWMM, Urban runoff.

\section{Introduction}

In line with the concept of sponge city, man-made structures are constructed to absorb stormwater across a city [1]. By having these small structures distributed along the flow path of stormwater runoff, parts of the waters are stored in the structure. As such, the less water quantity is discharged to the urban drains during a storm event. The stored water is then released after the drains are relieved, and the carrying capacities are increased [2]. Built-up surfaces in the city would cause the stormwater runoff to spike quickly. As depicted in Figure 1, such a condition is represented in the postdevelopment hydrograph shape, which is narrow and with steep limbs. On the other hand, the predevelopment hydrograph is represented by a lower peak, broader base and gentle limbs. The latter hydrograph shape is influenced by the filtration of stormwater to the soil layers and attenuation of flow due to natural vegetative covers.

\footnotetext{
*Author for correspondence
}

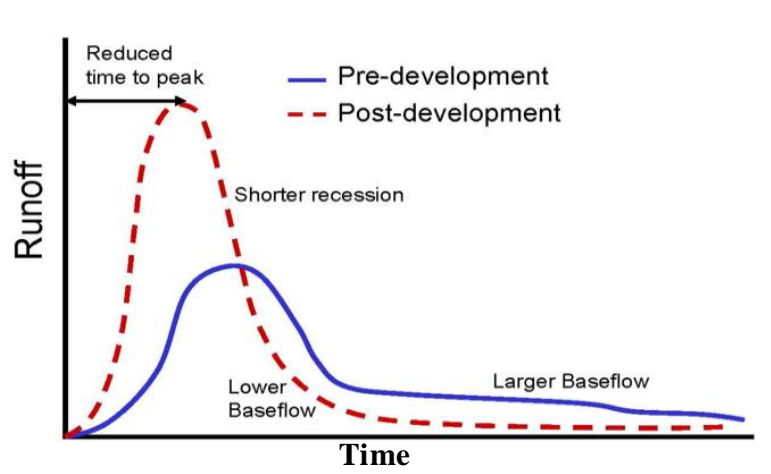

Figure 1 Stormwater runoff for pre- and postdevelopment conditions

From the perspective of engineering, hydrology, manmade structures could be designed to mimic the natural processes to lower the peak of the postdevelopment hydrograph to a near pre-development condition [3].

Availability of urban spaces to install stormwater storage structures pose as a challenge nowadays. 
Green strips with trees and plants are always suggested [4]. However, these are in smaller percentages than the built surfaces. Studies by Pour et al. [5] and Hamouz et al. [6] had suggested alternatives to explore the potential of built-up areas. In line with these research trends, this paper explores the applicability of fitting stormwater storage structure in shop buildings.

In Southeast Asian countries like Malaysia, Singapore, Thailand and Indonesia, a veranda in the shop building is common. The veranda is a building feature, in which the front wall of the shop building is pushed back for usually $3 \mathrm{~m}$ (or 5 feet) (Figure 2). Contrary to the United States and Europe, the veranda is usually an extension from the front wall of building [7].

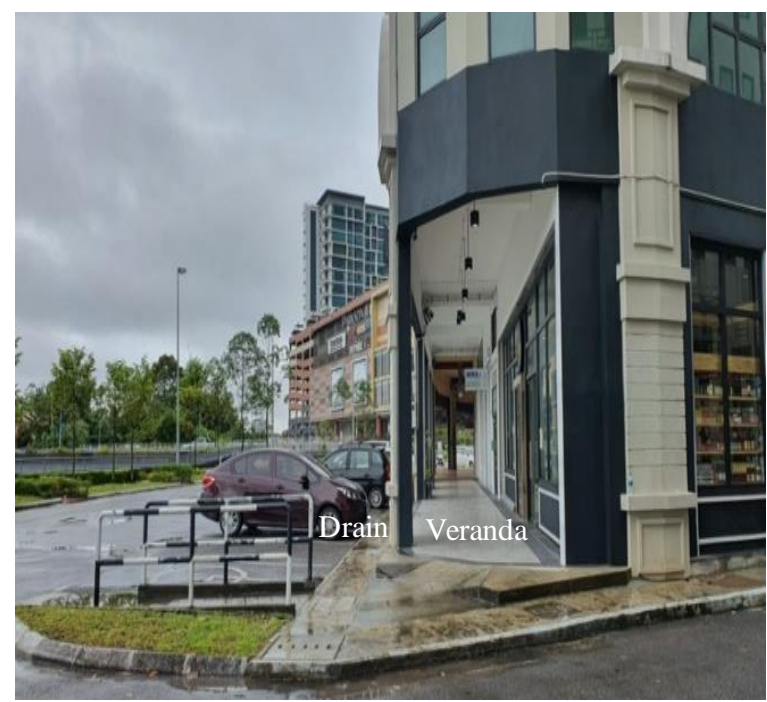

Figure 2 Shop buildings in Malaysia

The veranda forms a corridor in front of the shop. In the old days, the veranda was used for business and social activities where vendors displayed their goods and mingled with customers. Nowadays, it is a pedestrian walkway. In this study, the veranda presents as a location to be investigated for underground stormwater storage structure. The idea is to have the stormwater from the shop building's roof diverted to the stormwater storage structure under the walkway. A perimeter drain is usually placed in front of the shop, which can release stored water in the proposed structure.

\section{Literature review}

Stormwater storage structure captures running water on the ground surfaces and stores the water that resulted in slow releases of water to the waterways.
Examples of concrete-based storage structures are depicted in Figure 3.

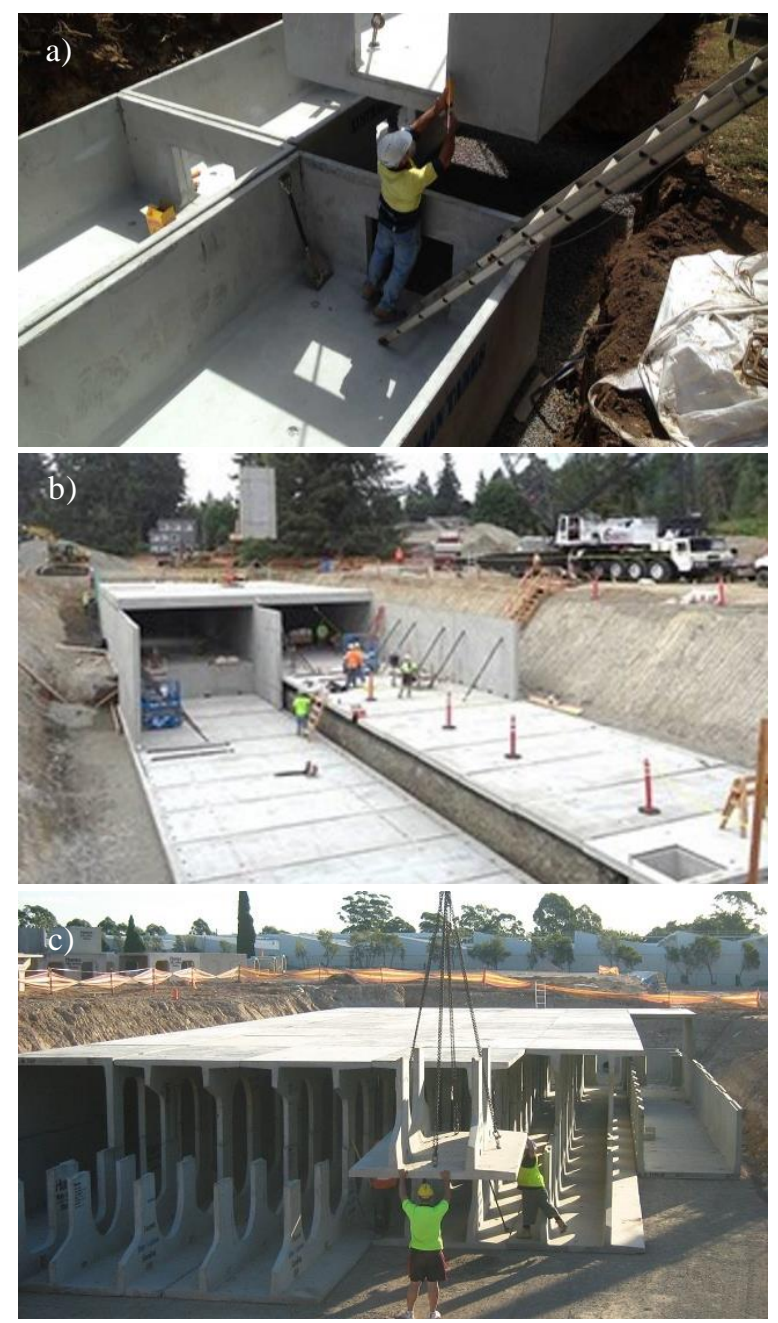

Figure 3 Types of stormwater storage structures, a) Tanks [8], b) Panels [9], c) Modular Units [10]

Structures in Figure $3 a$ are interlocked concrete tanks [8] while in Figure 3b, are multiple concrete panels assembled to form storage spaces [9]. On the other hand, the structures in Figure $3 c$ are concrete modular units that could be connected [10]. These are so called proprietary products that little literatures are available concerning them. It may either due to product owners treating their data as trade secrets or editors refusing publication related to the products to avoid commerciality.

The evolution of the stormwater storage structures has changed from a generally large to smaller and smaller in size. This was due to empty lands were more easily available in the old days. Despite so, the main function of stormwater detention remained to offset the impacts 
of urban development as highlighted in the studies of Li et al. [11], Ronalds and Zhang [12] and Birkinshaw et al. [13]. It was also reported that stormwater storage, improved the water quality in water flowing over the structure, as highlighted in the studies of Sharior et al. [14] and Braga et al. [15].

As empty lands are increasingly difficult to come by, it has come to a stage to fit stormwater storage structures into congested urban landscapes [16]. As one example, instead of stopping flooding, researchers explored the possibility of allowing selected urban roads as open floodways [17]. As reported by Sanieiet al. [18], replacing existing tarred road surfaces with permeable pavement could reduce flooding during wet seasons. Other studies in China as reported by Liu et al. [19] and Yang and Lee [20], urban spaces were optimally utilized to manage urban runoff instead of clearing new lands.

\section{Methods}

\subsection{Selected stormwater storage system}

A system consisted of modular precast concrete units is suggested in this study. The non-commercialized modular units are developed by the authors and their research team. Grade 50 concrete is used to fabricate the units. It was tested in the laboratory to withstand loading up to $100 \mathrm{kN} / \mathrm{m} 2$ [21]. A single modular unit is made up of three concrete pieces (Figure 4). The top and bottom layers are two identical $75 \mathrm{~mm}$ high hexagonal plates, with the top plate functions as pavement while the bottom plate acts as the unit's foundation. The middle layer is a $300 \mathrm{~mm}$ high hollow cylinder which functions as the water storage chamber. The single modular unit's total height is 0.45 $\mathrm{m}$, calculated to have a water storage capacity of 0.03 m3 per modular unit [22].

a)

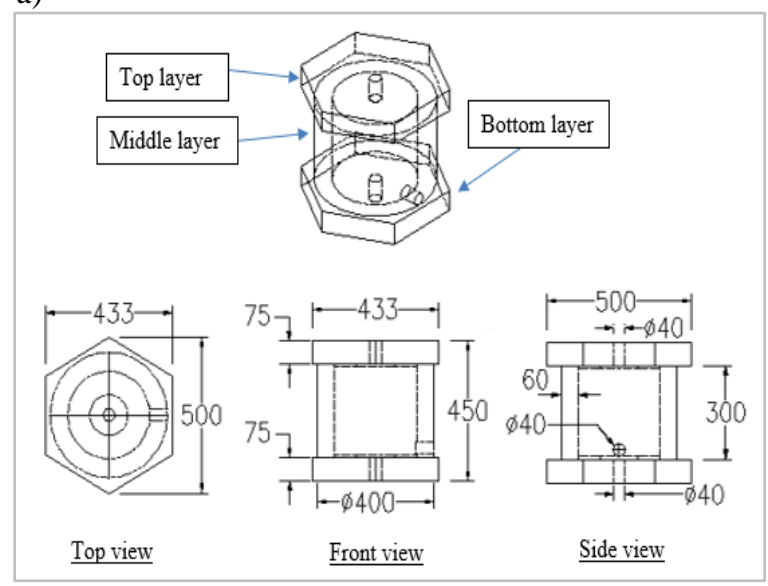

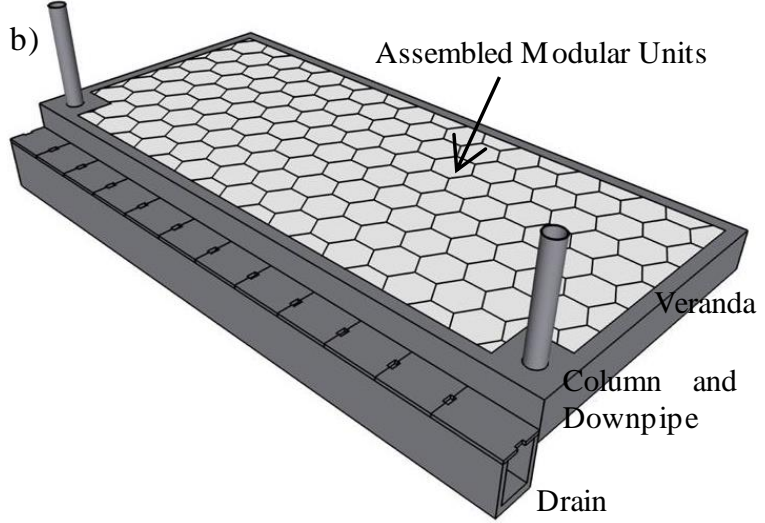

Figure 4 Stormwater storage structure in the veranda, a) Modular unit and b) 3D layout

\subsection{Field test}

A field test using the modular concrete units was conducted, and the findings were reported in [23, 24]. A total of 121 units of the said prototype were assembled in a voluntary house in Kuching city, Sarawak, Malaysia (Figure 5). The constructed tank had a surface area of $20.68 \mathrm{~m}^{2}$, calculated to have an effective storage of $3.92 \mathrm{~m}^{3}$. The system received water from the house's side veranda with a roof area of $95 \mathrm{~m}^{2}$ via a $0.1 \mathrm{~m}$ diameter downpipe. It released water via a $0.05 \mathrm{~m}$ diameter outlet pipe to the house's drain. Data collection period spanned from November 2019 to March 2020 that coincided with the Northeast Monsoon experienced in the Southeast Asian region. Two flowmeters were installed, one at the inlet and another at the outlet. Ultrasonic water level sensors were also installed to record the tank's rise and fall rate. Selected storm events and associated inflow, outflow and water level data from the field test were used to calibrate and verify the computer model that followed.

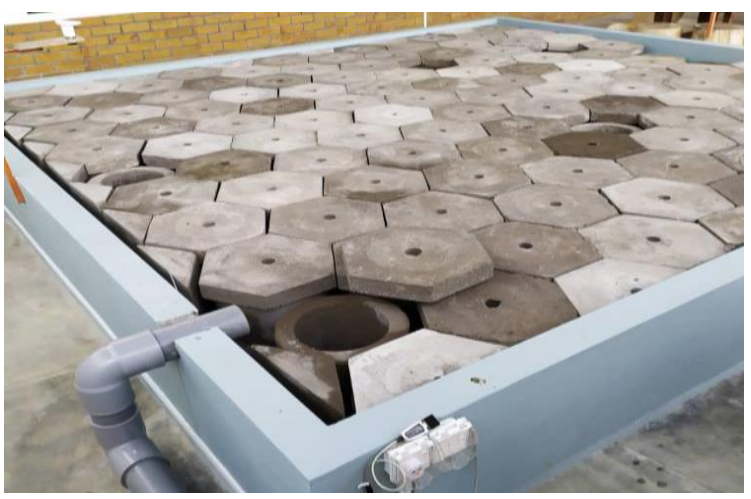

Figure 5 Field test 
3.3Study area

Before building a real-life stormwater storage system, it is common for drainage engineers to conduct investigative modelling of the system. An anonymous commercial area with two-row of shop buildings was chosen (see Figure 6).

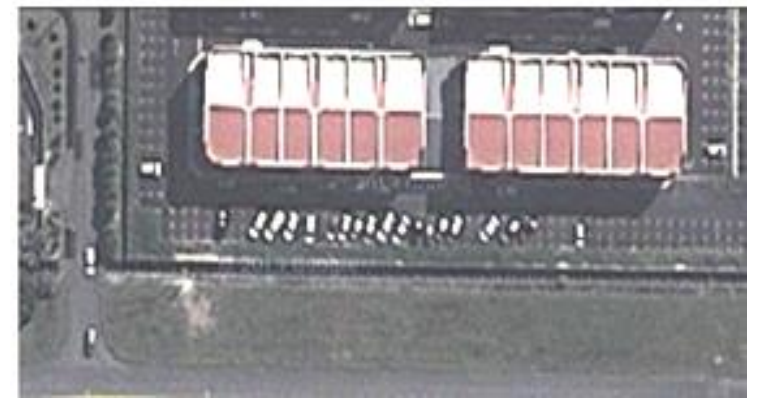

Figure 6 Study area

A study area allows a realistic representation of the site conditions. Each of the shops was $7 \mathrm{~m}$ in width and 18 $\mathrm{m}$ in length. Considering the veranda was $3 \mathrm{~m}$ wide, the veranda's surface area in front of each shop was calculated at $21 \mathrm{~m}^{2}(3 \mathrm{~m} \mathrm{x} 7 \mathrm{~m})$. The stormwater storage structure was assumed to be placed under the walkway. A brick wall was needed to encase the modular concrete units. Taking the brick width as 90 $\mathrm{mm}$, the would-be created tank's inner surface area was calculated as $19.23 \mathrm{~m}^{2}(2.82 \mathrm{~m} \times 6.82 \mathrm{~m})$, which required 118 modular units to fill up the tank. The inner surface area and the number of units calculated were close to the field test $\left(20.68 \mathrm{~m}^{2}\right.$ with 127 units $)$. Therefore, it was considered a similar build-up.
From Figure 6, the shop buildings were observed to have a simple gable roof. With a roof pitch at 5/12 ratio, each shop's total roof area was calculated at $136.5 \mathrm{~m}^{2}$. Half of the roof plane inclined to the front, while another half, to the back. Only $68.25 \mathrm{~m}^{2}$ front roof was directing the water into the stormwater storage structure on the first floor. There were two 0.5 $\mathrm{m} \times 0.5 \mathrm{~m}$ perimeter drains, one in front of and the other at the back of each shop. The streets were $8 \mathrm{~m}$ and $3 \mathrm{~m}$ wide in front and at the back of the shop, respectively. Stormwater generated from the roof and street surfaces were directed to the perimeter drains, then to $1 \mathrm{mx} 1 \mathrm{~m}$ drains surrounding the commercial area.

\subsection{Storm events}

Rainfall data were obtained through the mentioned field test. Eight storm events occurred between December 2019 and January 2020 were selected, generally perceived as the height of the Northeast Monsoon in Sarawak. According to the classification of rainfall by the Sarawak's Department of Irrigation and Drainage, there was one event under "light rainfall" (0.5-10 mm), five events under "moderate rainfall" (11-30 $\mathrm{mm})$ and two events under "heavy rainfall" (31-60 mm) categories. Unfortunately, no data from "very heavy rainfall" (61 $\mathrm{mm}$ and above) category was collected. These storm events with peak rainfall values ranging from 8.6 to $37.2 \mathrm{~mm}$ represented local frequent rainfall patterns. Referring to Table 1, Events 1 to 4 were used for model calibration, while Events 5 to 8 were used for model verification.

Table 1 Selected storm event

\begin{tabular}{lllll}
\hline S. No. & Event (yy.mm.dd) & Duration (hour) & Total Rainfall (mm) & Peak Rainfall (mm) \\
\hline 1 & 19.12 .02 & 8 & 52.8 & 12.5 \\
\hline 2 & 19.12 .11 & 15 & 31.6 & 8.6 \\
\hline 3 & 19.12 .28 & 9 & 59.5 & 22.3 \\
\hline 4 & 20.01 .18 & 8 & 66.4 & 34.4 \\
\hline 5 & 19.12 .30 & 7 & 39.6 & 18.3 \\
\hline 6 & 19.12 .22 & 8 & 60.0 & 21.9 \\
\hline 7 & 20.01 .19 & 7 & 60.0 & 22.8 \\
\hline 8 & 20.01 .20 & 11 & 85.6 & 37.2 \\
\hline
\end{tabular}

\subsection{Stormwater drainage modelling}

Storm Water Management Model (SWMM) version 5.0 under the United States Environmental Protection Agency's license was selected as the modelling platform here. The same software was used to model the modular concrete units as part of an urban stormwater drainage system, as reported in [25, 26].
A drainage network consisted of 1) rainfall, 2) catchment, 3) node, 4) link, 5) other stormwater components, and 6) outfall or final discharge point. Stormwater drainage modelling always started with rainfall, and the selected rainfall data were presented in Section 3.3. 
Referring to the study area in Section 3.2, catchments were taken as the shop building's roof and street surfaces. Rainfall on these impervious surfaces was transformed into running water or runoffs. These waters were directed to drain or stormwater storage structure. Drains were represented as nodes and links. Stormwater storage structure could be represented in several ways, but a study by Mah et al. [27] had suggested representing the structure as a storage unit with orifice outlet.

SWMM computed the flow of running waters from catchments based on Equation (1).

$Q=W \frac{1.49}{n}\left(d-d_{p}\right)^{5 / 3} S^{1 / 2}$

where,

$Q=$ Water flow from the catchment $\left(\mathrm{m}^{3} / \mathrm{s}\right)$;

$W=$ Width of roof or street $(\mathrm{m})$;

$S=$ Slope of roof or street (m);

$n=$ Manning roughness value (unitless);

$d_{p}=$ Maximum depression storage (m);

$d=$ Depth of water over the catchment (m).

Parameters like the width, $W$ and slope, $S$ of catchments were measured in the study area. Maximum depression storage, $d_{p}$ and the associated water depth, $d$ were parameters that could be observed and measured during storm events in the study area as well. The remaining parameter, Manning's $n$ value, could be obtained with model calibration [28].

Once the running waters entered the drain, the water flow in the drain's channel was routed from node to node until it reached the outfall. The routing was based on the kinematic wave approximation in Equation (2), which is numerically solved in SWMM.

$q=\frac{\partial A}{\partial t}+\alpha m A^{(m-1)} \frac{\partial A}{\partial x}$

where,

$q=$ Routed water flow $\left(\mathrm{m}^{3} / \mathrm{s}\right)$;

$A=$ Cross sectional area of drain $\left(\mathrm{m}^{2}\right)$;

$x=$ Distance along the flow path (m);

$t=$ Time step (s);

$\alpha=$ Flow geometry due to drain (unitless);

$m=$ Surface roughness of drain (unitless).

Parameters in Equation (2) could be measured physically (for the cross-sectional area, $A$ and distance, $x$ ) or referred to design guidelines (for flow geometry, $\alpha$ and surface roughness, $m$ ). Time step, $t$ could be obtained with model calibration [28].

In the case of the selected modular unit, it contains of solid concrete wall and empty space. Due to its fixed geometry, the volume of solid concrete wall could be calculated. Subtracting the gross volume of modular unit with the calculated volume of solid concrete wall, the remaining is the empty space that is called effective storage volume. The modular unit has an effective volume calculated at $0.19 \mathrm{~m}^{3} / \mathrm{m}^{2}$ of pavement [27]. SWMM represented the storage unit as water volume being captured over time, as shown in Equation (3). The volume, referred to the effective storage volume, defined as the storage curve in SWMM. The inflow was from the routed flow before the storage unit. Outflow was due to the orifice outlet attached to the unit, as shown in Equation (4).

$S t=\sum_{i}\left(q-Q_{0}\right) \Delta t$

where,

$S t=$ Storage volume $\left(\mathrm{m}^{3}\right)$;

$q=$ Inflow/routed water flow $\left(\mathrm{m}^{3} / \mathrm{s}\right) ;$

$Q_{\mathrm{o}}=$ Outflow/flow from orifice outlet $\left(\mathrm{m}^{3} / \mathrm{s}\right)$;

$t=$ Duration of storm (s).

Waters flowing out of the orifice outlet was defined as Equation (4):

$Q_{o}=A_{o} C_{o} \sqrt{2 H_{o} g}$

where,

$Q_{o}=$ Flow from orifice outlet $\left(\mathrm{m}^{3} / \mathrm{s}\right)$;

$A_{o}=$ Orifice diameter $\left(\mathrm{m}^{2}\right)$;

$C_{o}=$ Discharge coefficient of orifice (unitless);

$H_{o}=$ Maximum head to the centre of the orifice (m);

$g=$ Acceleration due to gravity $\left(\mathrm{m} / \mathrm{s}^{2}\right)$.

Design of the storage unit and orifice outlet followed the field test $[23,24]$. The diameter of circular orifice outlet, $A o$ for the modular system was found best at $0.05 \mathrm{~m}$. Discharge coefficient, $C o$ for the orifice was best at 0.06 . Acceleration, $g$ was taken as $9.81 \mathrm{~m} / \mathrm{s}^{2}$. Maximum head, $H o$ was measured at $0.425 \mathrm{~m}$.

Finalized SWMM models are presented in Figure 7. 

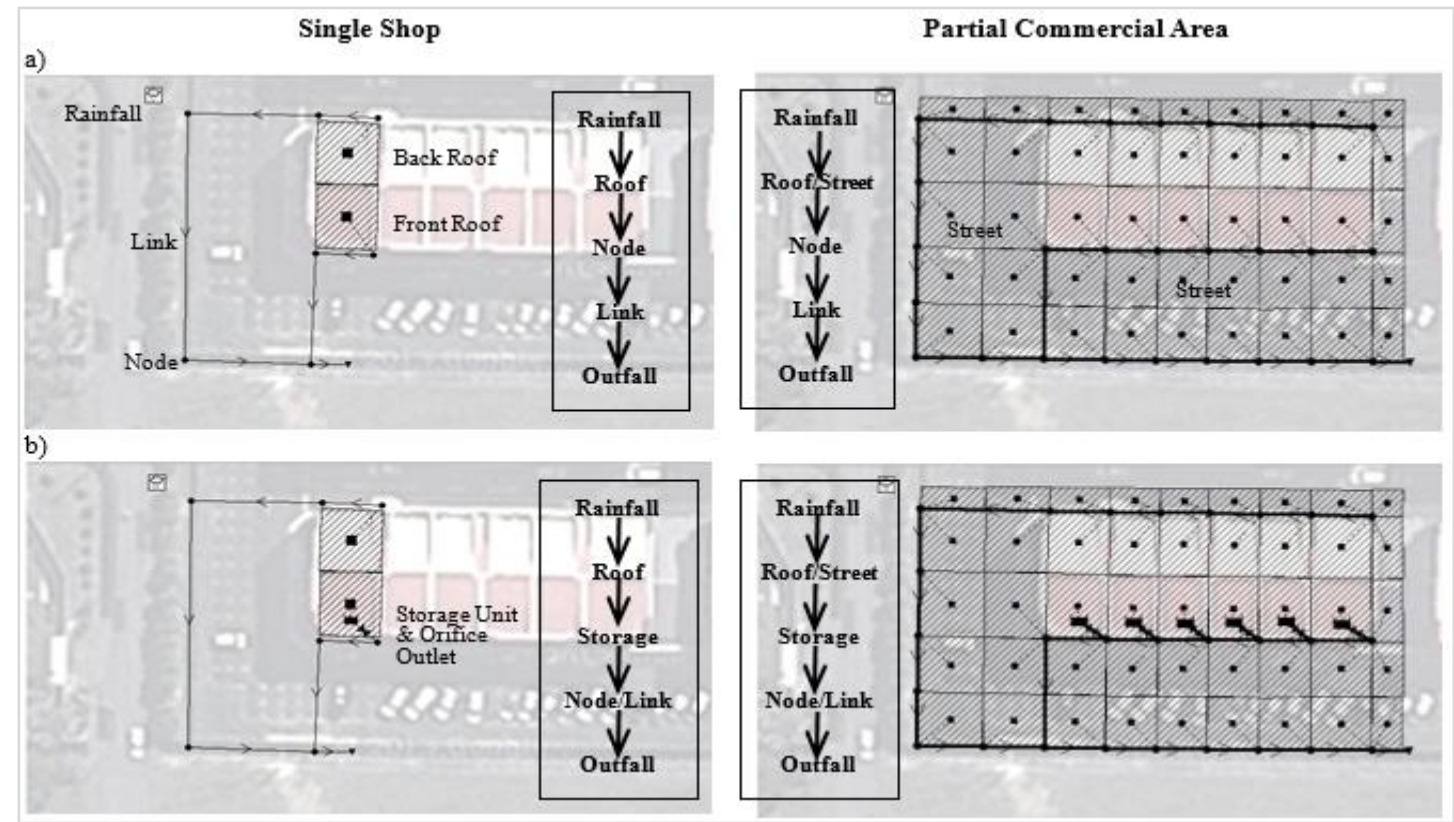

Figure 7 Developed SWMM models for a) Conventional drainage and b) Drainage with stormwater storage structure

\subsection{Model calibration}

Model calibration was carried out with four selected storm events. The outcomes are presented in Figure 8. Each storm event is presented in two sub-figures, one with combined rainfall, inflow and outflow, and another with water level only.

With a flowmeter at the inlet, water that enters the stormwater storage is recorded as time series of inflow data; and with another flowmeter at the outlet, water that leaves the stormwater storage is recorded as time series of outflow data. These inflow and outflow appear as bell-shaped graphs, in which it rises as a storm increases its intensity until it reaches a peak, then it falls as the storm subsides slowly. On the other hand, with an ultrasonic level sensor, the water level in the stormwater storage is recorded as time series of water level data. Its shape follows the shapes of inflow and outflow as the stormprogresses till it stops. These time series of inflow, outflow and water level data are termed observed hydrographs. The calibration exercises had determined that the Manning's $n$ value for the roof and street catchment was best at 0.022 , and the time step was best at $30 \mathrm{~s}$.

\subsection{Model verification}

Model verification was carried out with another four storm events secluded from those chosen for the calibration. With the calibrated values stated above, the selected four storm events were running through the SWMM model. The observed and predicted inflow, outflow and water level data are compared in Figure 9.

\subsection{Goodness of fit}

Observed hydrographs are plotted in lines, while the predicted hydrographs are plotted in markers. The fitting was quantified with scatter plots of observed and predicted values in Figure 10. For model calibration, $\mathrm{R}$ square values obtained ranged from 0.98-0.99, indicating close matches.

For model verification, $\mathrm{R}$ square values obtained ranged from 0.97-0.99. The close matches obtained in the verification exercises indicated that the SWMM model for the type of selected water storage structure could be well represented and duplicated for the case study of the veranda in a shop building. 
Darrien Y.S. Mah et al.

a)
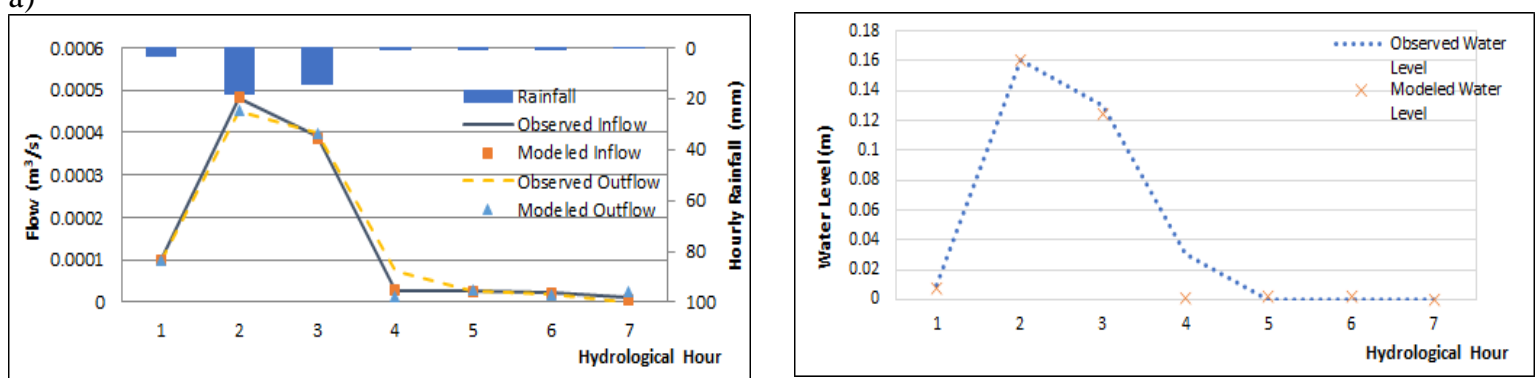

b)
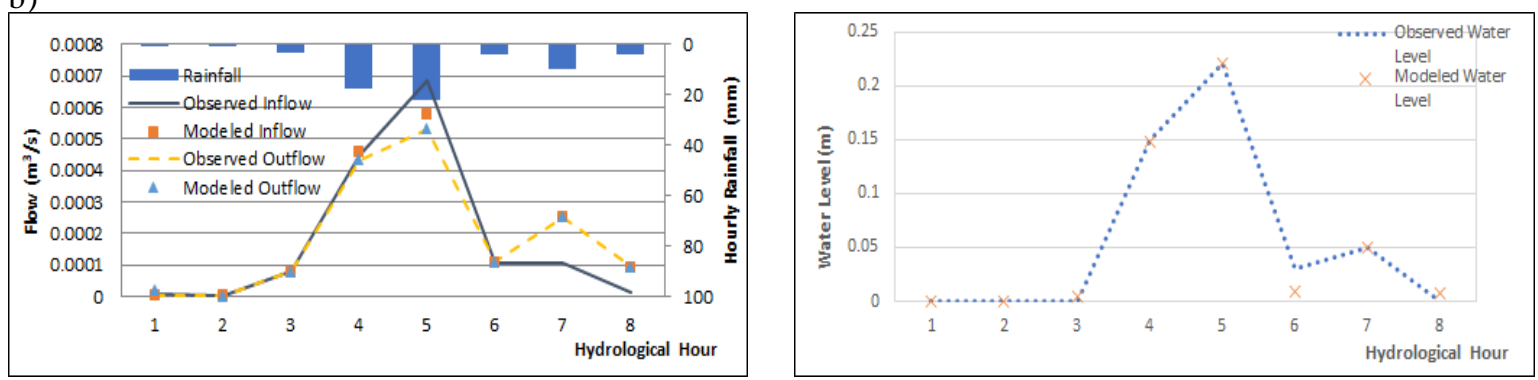

c)
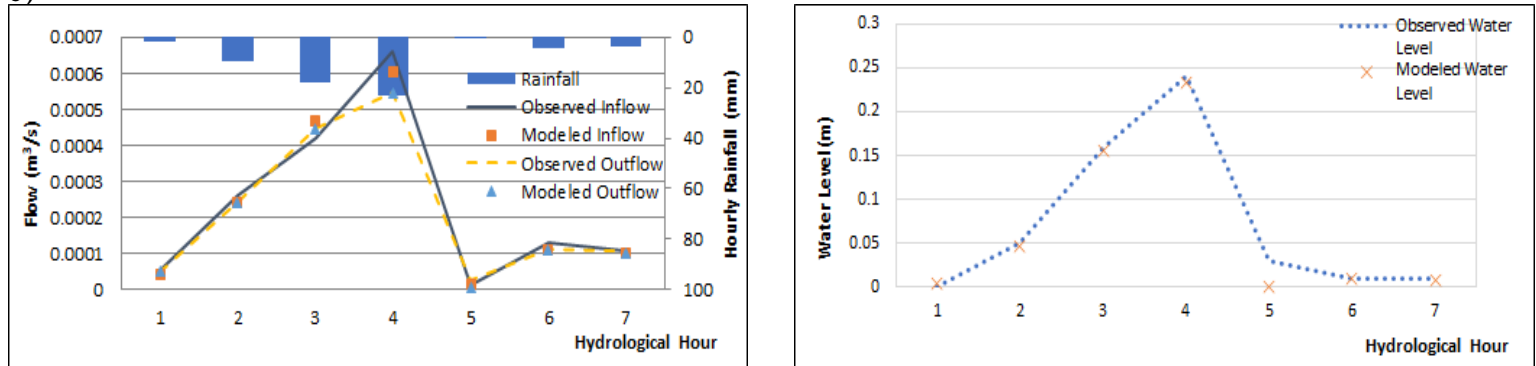

d)
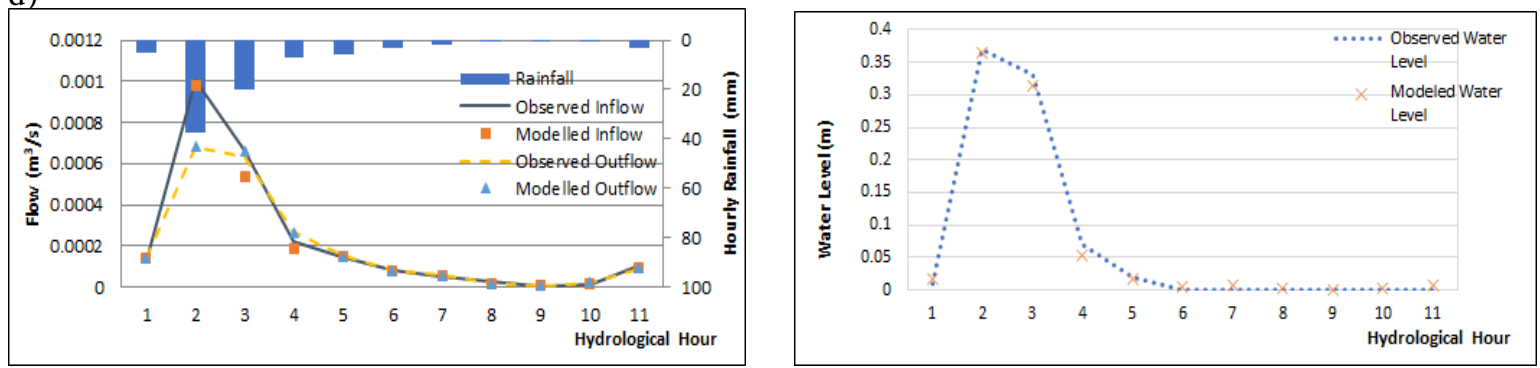

Figure 8 Calibration of stormwater storage structure in terms of inflow, outflow and water level associated with a) 02.12.2019, b) 11.12.2019, c) 28.12.2019, and d) 18.01.2020 storm events 
International Journal of Advanced Technology and Engineering Exploration, Vol 8(82)

a)

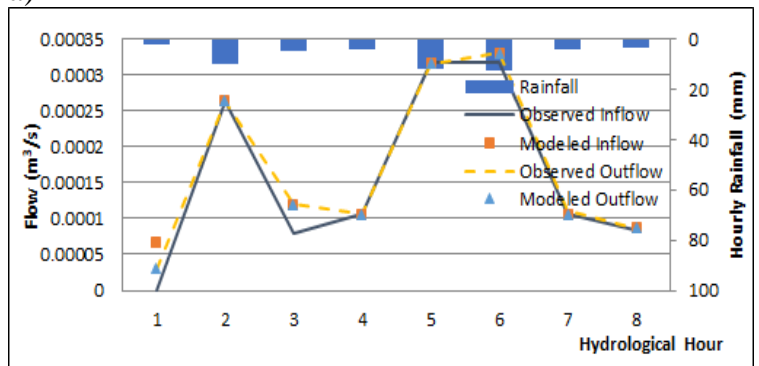

b)

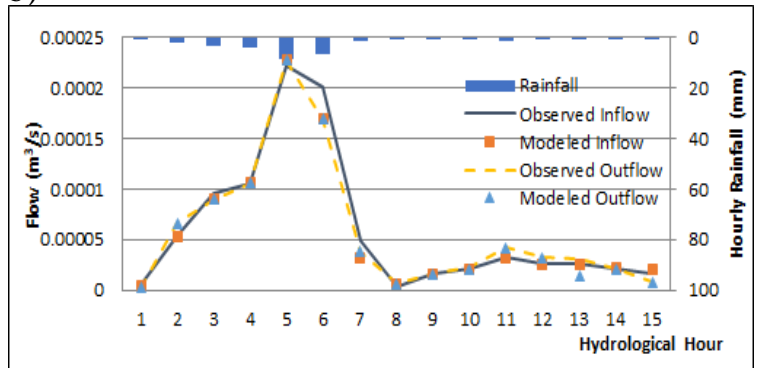

c)

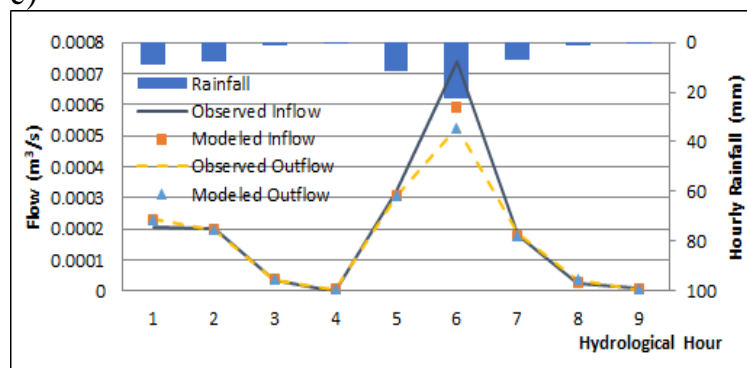

d)

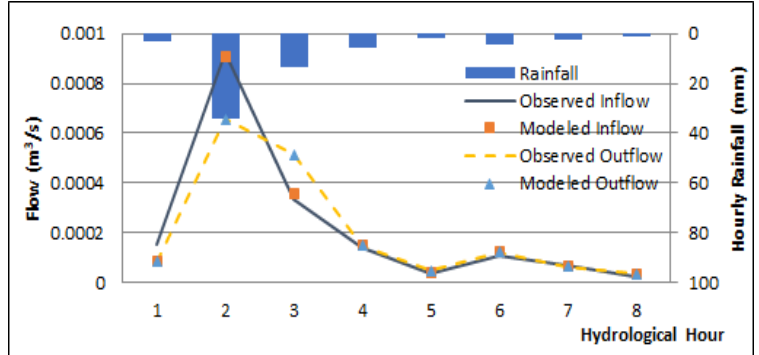

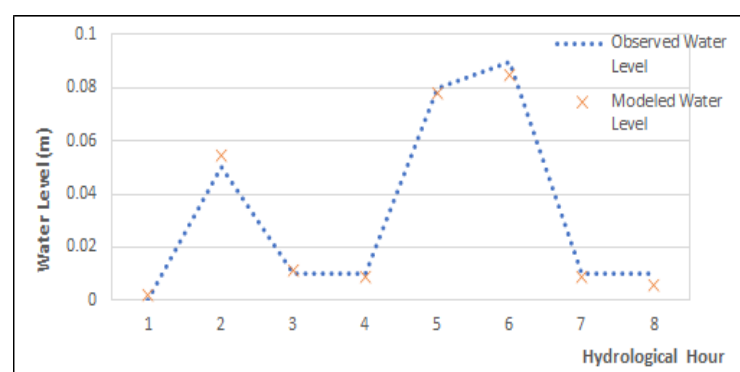
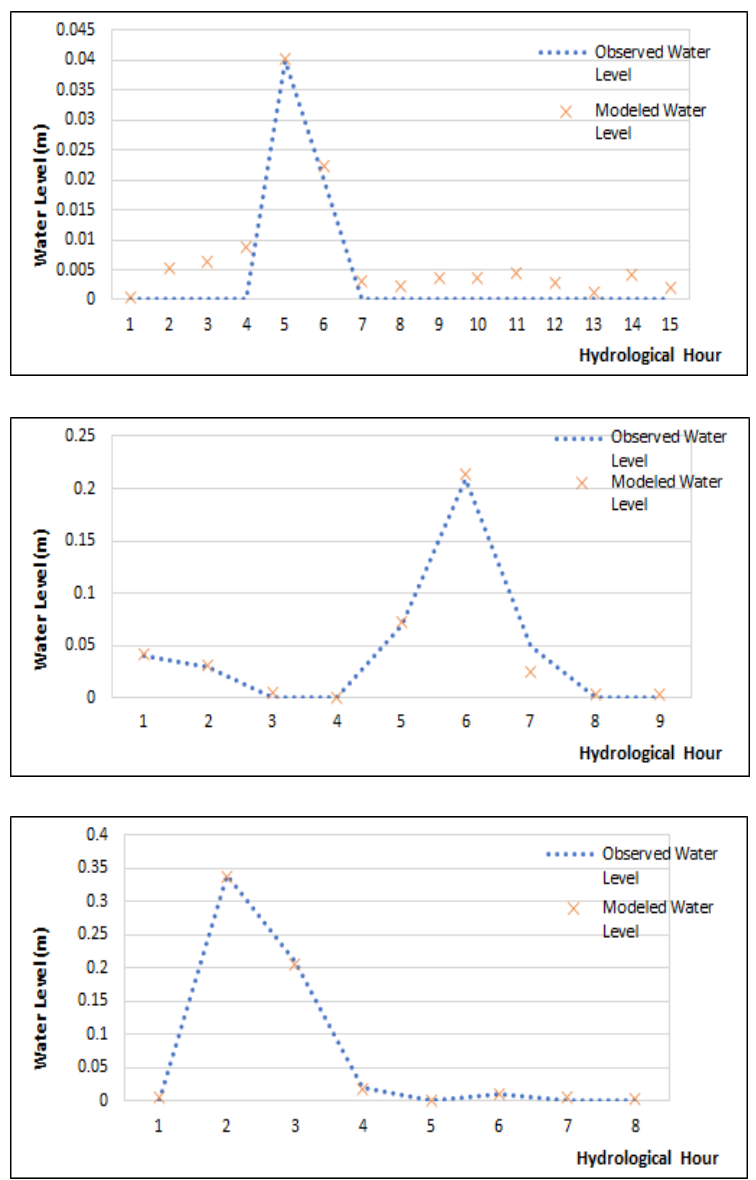

Figure 9 Verification of stormwater storage structure in terms of inflow, outflow and water level associated with a) 30.12.2019, b) 22.12.2019, c) 19.01.2020, and d) 20.01.2020 storm events 

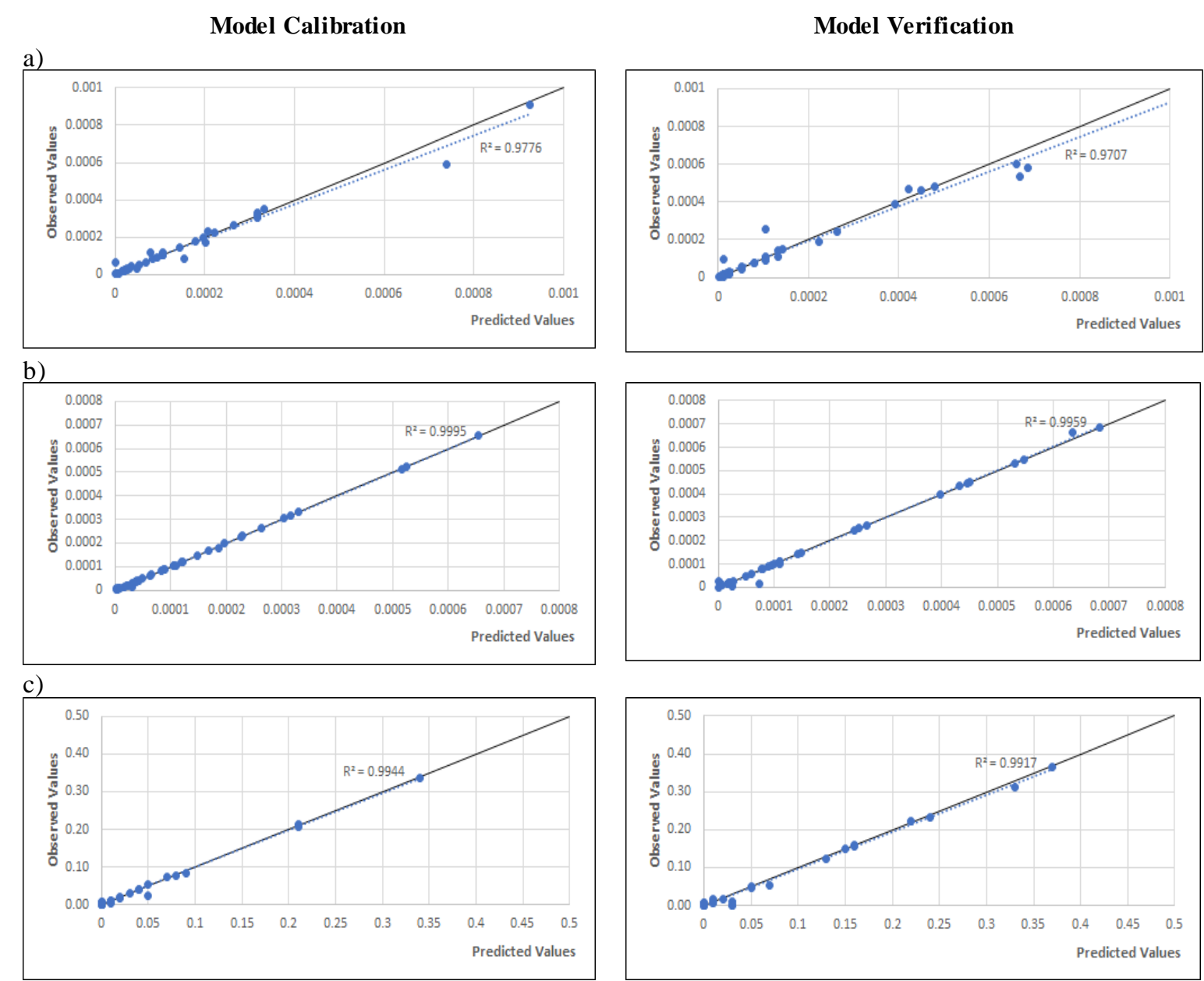

Figure 10 Scatter plots for calibration and verification in terms of a) Inflow, b) Outflow and c) Water level in the stormwater storage structure

\section{Results}

Performances of stormwater storage structures are benchmarked to the pre- and post-development hydrographs illustrated in Figure 1. An effective newly introduced human intervention in the stormwater flow shall have a hydrograph with a peak lower than the post-development hydrograph and the extent of the reduction shall near the pre-development hydrograph as much as possible.

The eight storms that were previously used in the calibration and verification of field tests were subjected to the commercial area. Two modelling cases of stormwater storage structure in the veranda of shop building are presented in this study. The analyses that followed are comparisons of the hydrographs due to the modified veranda with pre- and postdevelopment hydrographs. Scenarios of reduction in the peak hydrographs are reported.

\subsection{Single shop}

The first case involved only a single shop. The roof catchment $\left(136.5 \mathrm{~m}^{2}\right)$ of the shop was separated into two sub-catchments. By modelling both the subcatchments as equal areas at $50 \%\left(68.25 \mathrm{~m}^{2}\right)$, the results of the hydrographs were insignificant. With $50 \%$ of the roof catchments directing waters to the water storage structure, reduction rates of peak postdevelopment hydrographs with the intervention were found to range between 0.7 to $7 \%$ compared with the post-development hydrographs without intervention.

The authors followed the findings in [29] to increase the front roof sub-catchment area to $60 \%\left(81.9 \mathrm{~m}^{2}\right)$ and decrease the back roof sub-catchment area to $40 \%$ $\left(54.6 \mathrm{~m}^{2}\right)$. With $60 \%$ of the roof catchments directing water to the water storage structure, the reduction rates were found to range between 25 to $31 \%$ (Table 2). The water storage structure was modelled as a draining tank which received and released water at the same 
time, and therefore the mentioned reductions were not proportioned to the catchment size.

a)

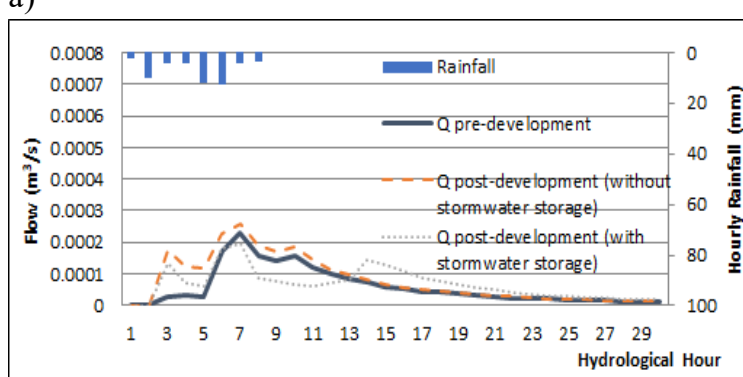

b)

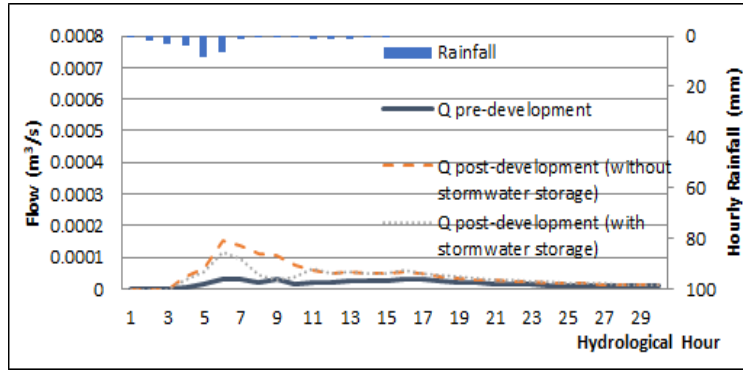

c)

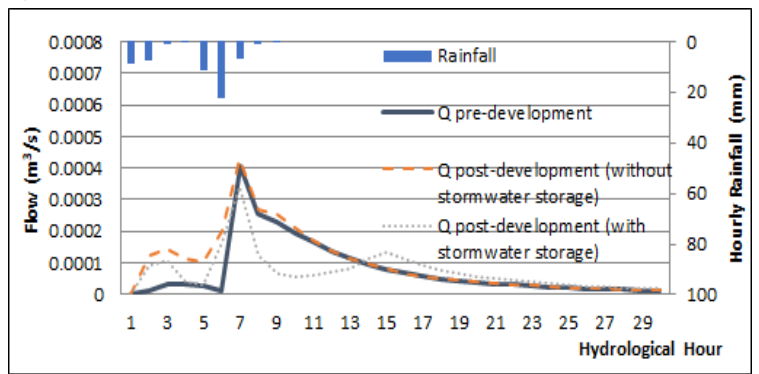

d)

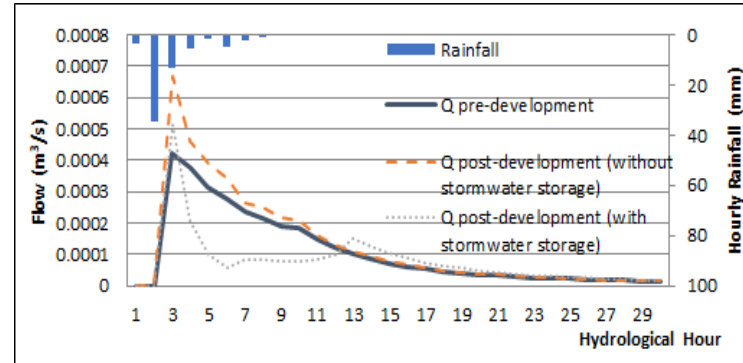

The resulted hydrographs are presented in Figure 11.

e)

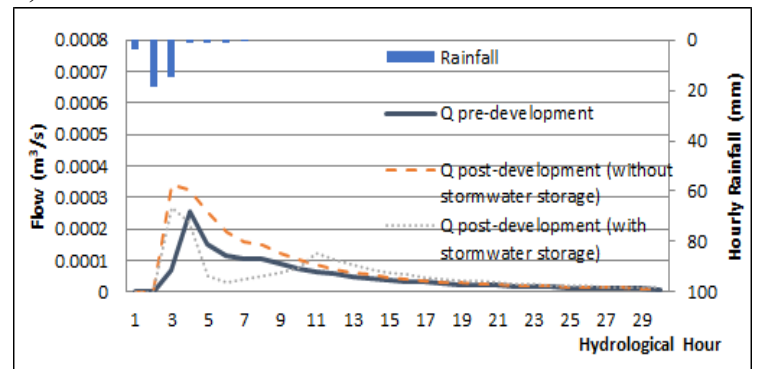

f)

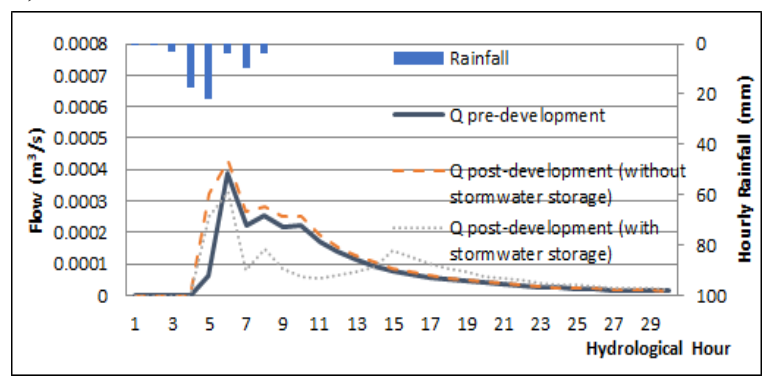

g)

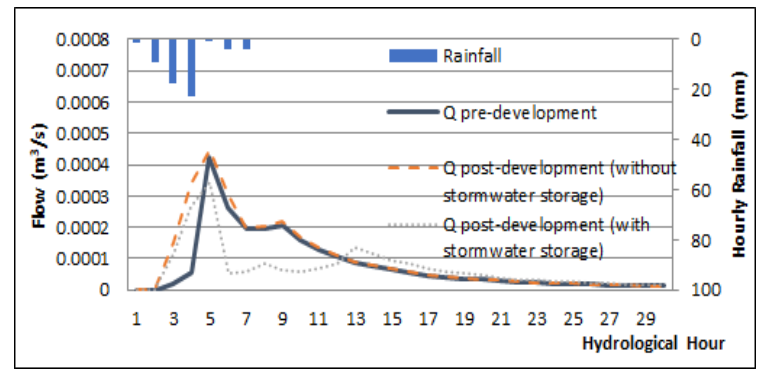

h)

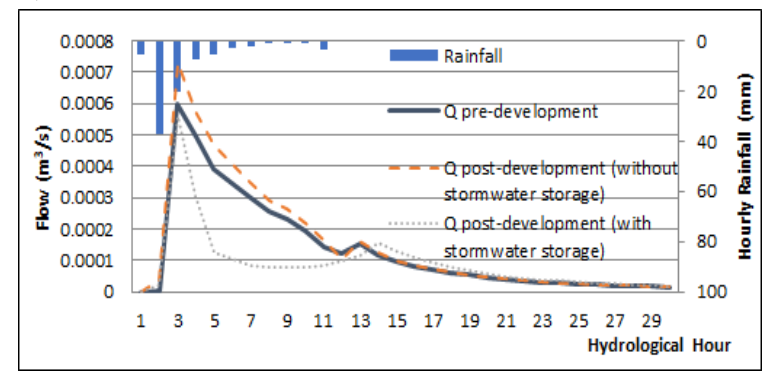

Figure 11 Predicted hydrographs at the outfall for single shop subjected to a) 02.12.2019, b) 11.12.2019, c) 28.12.2019, d) 18.01.2020, e) 30.12.2019, f) 22.12.2019, g) 19.01.2020, and h) 20.01.2020 storm events

\subsection{Partial commercial area}

The second case involved a row of shop buildings that consisted of six units of the shop and the surrounding streets. The total area of the partial commercial area was calculated at $1,566 \mathrm{~m}^{2}$, in which the shops constituted $48 \%\left(756 \mathrm{~m}^{2}\right)$ and the streets, $52 \%(810$ $\mathrm{m}^{2}$ ) of land areas. When the catchment areas of the front and back roof were $50 \%$ each, it was calculated to constitute $24 \%\left(378 \mathrm{~m}^{2}\right)$ of the total area. In this case, the reduction rates comparing the peak values of post-development scenarios with and without intervention were low, ranging from 0.1 to $7 \%$. The scenario of applying the ratio of 60:40\% in front and back roof sub-catchments were calculated to have $29 \%$ $\left(453.6 \mathrm{~m}^{2}\right)$ from the total area directing water to the water storage structure. The resulted hydrographs at 
outfall are presented in Figure 12, whereby the graphs are closely packed, but the peak values could be referred to in Table 2. The reduction rates were low, ranging from 0.4 to $10 \%$. The runoffs generated by

a)

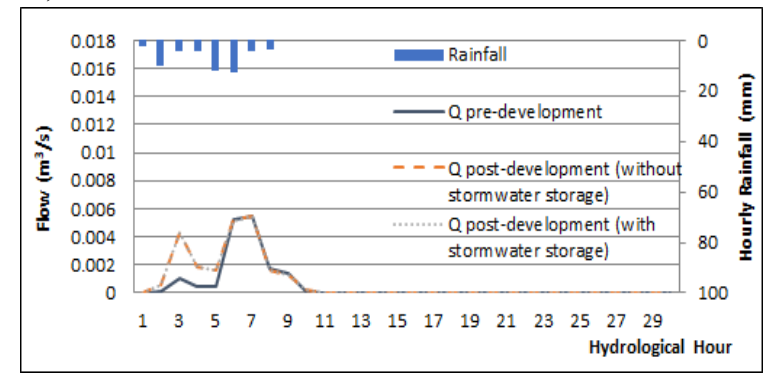

b)

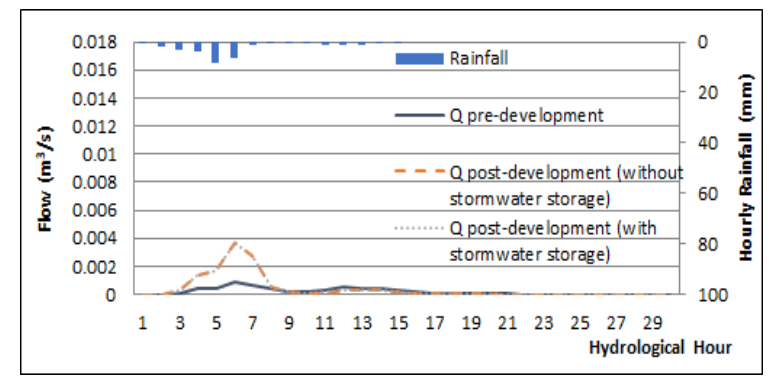

c)

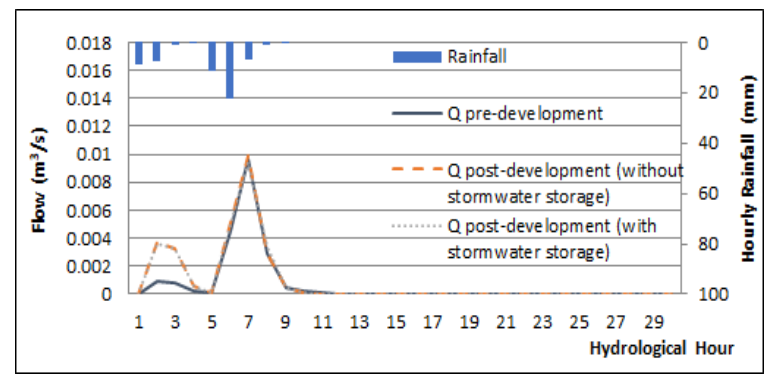

d)

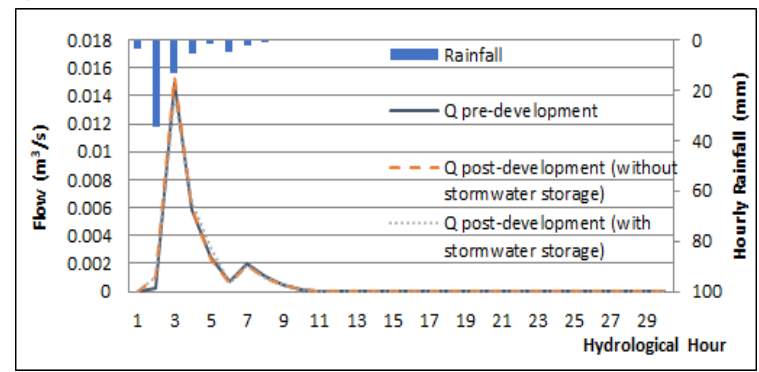

$71 \%$ of the total area without intervention overwhelmed the impacts of water storage structure at the individual lot.

e)

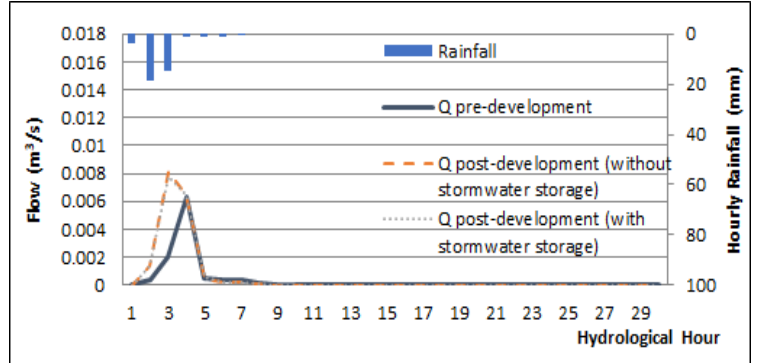

f)

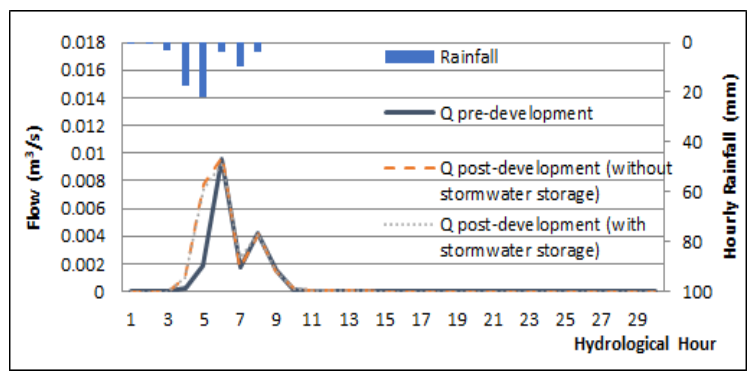

g)

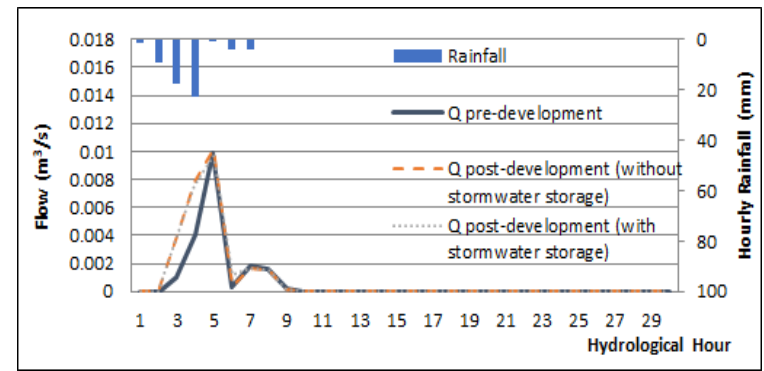

h)

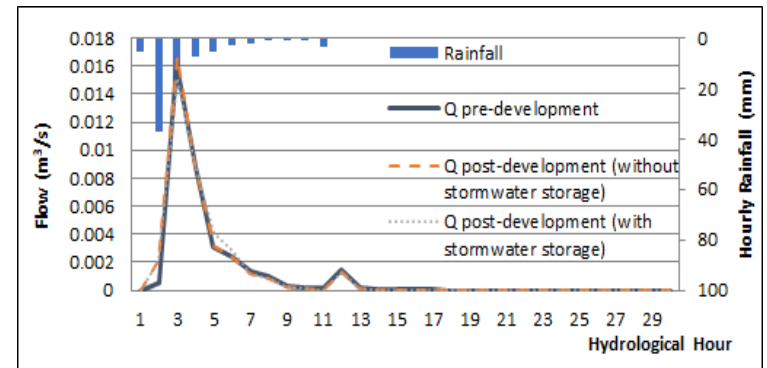

Figure 12 Predicted hydrographs at the outfall for commercial area subjected to a) 02.12.2019, b) 11.12.2019, c) 28.12.2019, d) 18.01.2020, e) 30.12.2019, f) 22.12.2019, g) 19.01.2020, and h) 20.01.2020 storm events 
Table 2 Predicted peak hydrograph values at the outfall

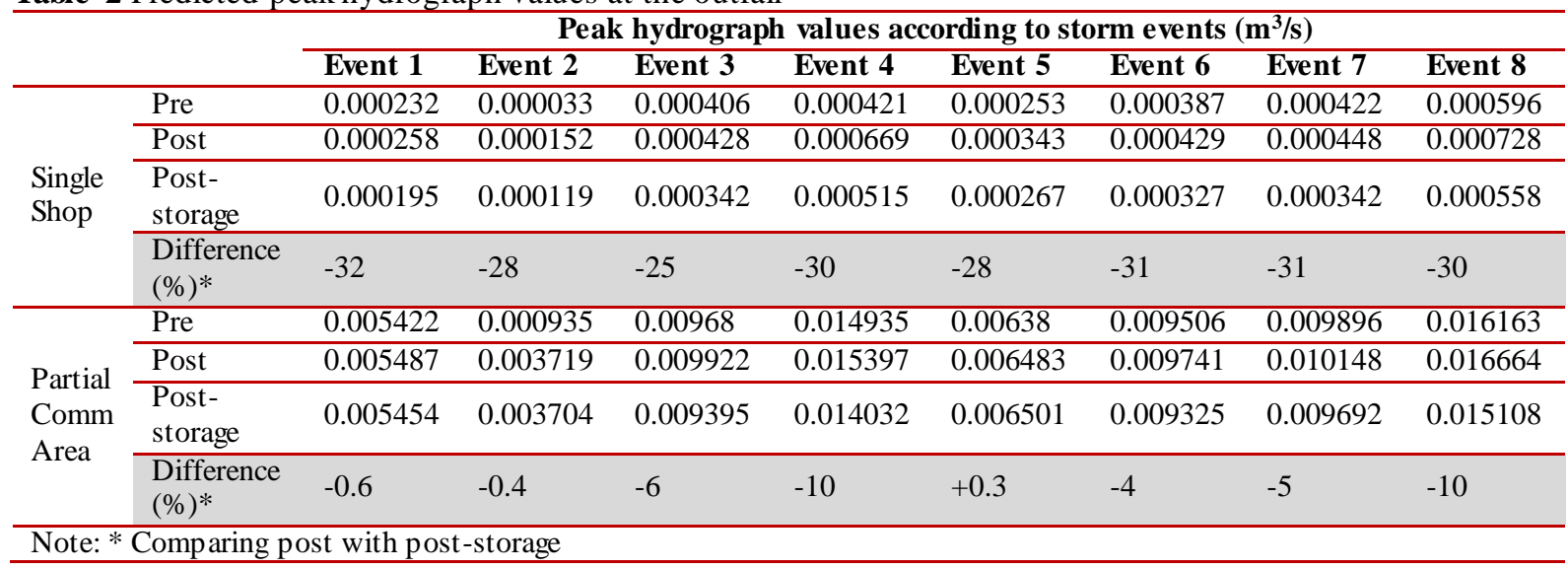

\section{Discussion}

It was found that, other than the rainfall intensities and stormwater storage volume, another critical factor that contributed significantly to the reduction of peak hydrographs was the catchment area that contributing water to the water storage structure.

The first scenario, using a single shop lot as an illustration, it was found at least $60 \%$ of the shop lot was required to have $25-31 \%$ reduction of postdevelopment peak hydrographs. Generally, in this scenario, all the post-development scenarios with intervention achieved near pre-development conditions, except for Event 2 (Figure 11b).

The second scenario, using partial commercial area that made up of six shop lots and surrounding roads, continued with the assumption $60 \%$ of each shop lot is contributing water to the water storage structure, the mentioned area was only $29 \%$ of the total area. As such, the runoff of the remaining $71 \%$ area was still overwhelming to cause high peaks throughout in this second scenario, and low reduction of between 0.4 $10 \%$ was estimated, except for Event 5 (Figure 12e).

Findings from a past study of Jiang and McBean [30] showed that lot-level structures could produce a $58 \%$ reduction of runoff volume for a 2-year storm, and $20 \%$ reduction for a 100-year storm. Compared with the findings from this study, the estimated maximum $31 \%$ reduction for a single shop lot that was equivalent to lot-level simulation, was within the range reported by Jiang and McBean.

However, the estimated maximum $10 \%$ reduction in the partial commercial area, or equivalent to catchment-wide simulation, the low performance was limited to the conditions of the study area (48\% of surfaces and $52 \%$ of the roads). Commercial areas come with different building layouts. We may need to test the concept in different commercial areas to have a more solid conclusion.

Despite so, Anderson et al. [31] had expressed that lotlevel structures on their own provided less reduction in runoff volume, but improved the catchment-wide integrated management plan. According to Jayakaran et al. [32], efforts were continued to encourage lotlevel structures close to the source of runoff production to manage smaller high frequency storms.

\section{Conclusions and future work}

The eight storm events running through the singleshop SWMM model was contained within the shop's veranda's limited space. The setup of the selected water storage structure had reduced the peaks of postdevelopment scenarios with and without intervention in the individual lot by $25-31 \%$. The structure was intended as a draining tank and the outcomes for the individual lot were acceptable.

However, the eight storm events running through the partial-commercial-area SWMM model had little reduction between 0.4 to $10 \%$ in peak values of postdevelopment hydrographs. Only $29 \%$ of total areas were connected to the water storage structure, which contributed to the low performances.

It can be deduced that intervention with water storage structure could lower the peak post-development hydrograph at the lot-level, but it was found inadequate to lower the peak of the catchment-wide hydrograph. As such, another intervention in the streets surrounding the shop buildings may improve stormwater control. This opens a res earch opportunity to extend the modular units not only under the veranda, 
but also under the car parking lots in front of the shop buildings in future work.

\section{Acknowledgment}

The authors acknowledged the financial support from the SDG Research@Borneo grant scheme (Project ID GL/F02/MCUN/14/2020), rendered by the Malaysian Comprehensive University Network (MCUN).

\section{Conflicts of interest}

The authors have no conflicts of interest to declare.

\section{References}

[1] Nguyen TT, Ngo HH, Guo W, Wang XC. A new model framework for sponge city implementation: emerging challenges and future developments. Journal of Environmental Management. 2020; 253.

[2] Li Q, Wang F, Yu Y, Huang Z, Li M, Guan Y. Comprehensive performance evaluation of LID practices for the sponge city construction: a case study in Guangxi, China. Journal of Environmental Management. 2019; 231:10-20.

[3] Li Y, Li HX, Huang J, Liu C. An approximation method for evaluating flash flooding mitigation of sponge city strategies-a case study of central Geelong. Journal of Cleaner Production. 2020.

[4] Pickett ST, Cadenasso ML, Mcgrath B. Resilience in ecology and urban design: linking theory and practice for sustainable cities. Springer Science \& Business Media. 2013

[5] Pour SH, Abd WAK, Shahid S, Asaduzzaman M, Dewan A. Low impact development techniques to mitigate the impacts of climate-change-induced urban floods: current trends, issues and challenges. Sustainable Cities and Society. 2020.

[6] Hamouz V, Pons V, Sivertsen E, Raspati GS, Bertrandkrajewski JL, Muthanna TM. Detention-based green roofs for stormwater management under extreme precipitation due to climate change. Blue-Green Sy stems. 2020; 2(1):250-66.

[7] Feng K, Gao H, Meng G, Li Q. The analy sis of veranda style architecture on modern times in qinhuangdao. Advanced Materials Research. 2015:2642-5. Trans Tech Publications Ltd.

[8] https://australiantanks.com.au. Accessed 12 July 2021.

[9] https://oldcastleinfrastructure.com. Accessed 12 July 2021.

[10] https://stormwatersy dney .com. Accessed 13 July 2021.

[11] Li F, Yan XF, Duan HF. Sustainable design of urban stormwater drainage systems by implementing detention tank and LID measures for flooding risk control and water quality management. Water Resources Management. 2019; 33(9):3271-88.

[12] Ronalds R, Zhang H. Assessing the impact of urban development and on-site stormwater detention on regional hydrology using Monte Carlo simulated rainfall. Water Resources Management. 2019; 33(7):2517-36.
[13] Birkinshaw SJ, Kilsby C, O'donnell G, Quinn P, Adams R, Wilkinson ME. Stormwater detention ponds in urban catchments - analysis and validation of performance of ponds in the ouseburn catchment, newcastle upon Tyne, UK. Water. 2021; 13(18):1-20.

[14] Sharior S, Mcdonald W, Parolari AJ. Improved reliability of stormwater detention basin performance through water quality data-informed real-time control. Journal of Hy drology . 2019; 573:422-31.

[15] Braga MR, Galileu SL, Tomazini DCF, Teodoro DSMS, Busquets R, Cintra CL. Stormwater detention reservoirs: an opportunity for monitoring and a potential site to prevent the spread of urban microplastics. Water. 2020; 12(7):1-15.

[16] Jia J, Zlatanova S, Hawken S, Zhang KF. Making smart urban decisions: the niche of a parametric spatial model to balance the needs of urban stormwater management and human wellbeing. ISPRS Annals of Photogrammetry, Remote Sensing \& Spatial Information Sciences. 2020; 6(4):79-86.

[17] Skrede TI, Muthanna TM, Alfredesen K. Applicability of urban streets as temporary open floodways. Hydrology Research. 2020; 51(4):621-34.

[18] Saniei K, Yazdi J, Majdzadehtabatabei MR. Optimal size, type and location of low impact developments (LIDs) for urban stormwater control. Urban Water Journal. 2021; 18(8):585-97.

[19] Liu J, Zhang L, Chen Y, Zhang Q. Constructing the landscape security pattern of urban stormwater in Nanjing, China. In proceedings of the institution of civil engineers-water management 2021 (pp. 53-69). Thomas Telford Ltd.

[20] Yang B, Lee D. Urban green space arrangement for an optimal landscape planning strategy for runoff reduction. Land. 2021; 10(9):1-12.

[21] Ngu JO, Mah DY, Bong CH. Flow characteristics of individual lot stormwater detention. Water Practice and Technology. 2016; 11(4):721-7.

[22] Mah DYS, Liow CV, Mannan MA. Application of stormpav green pavement system in a government buildings redevelopment scheme. International Journal of Innovative Technology and Exploring Engineering. 2019; 8(9):723-727.

[23] Ngu JO, Mah DY, Taib SN, Mannan MA, Chai SL. Evaluating the efficiency of household stormwater detention system. ASEAN Engineering Journal. 2021; 11(1):105-14.

[24] Mah DY, Ngu JO, Bustami RA, Putuhena FJ. Case study of modular pre-cast concrete on-site stormwater detention system during monsoon season in southeast Asia. Applied Environmental Research. 2021; 43(1):28-40.

[25] Liow CV. Mah DYS. Zainol MRRMA. Modelling of stormpav green pavement system with storm water management model and infoworks collective system. International Journal of Recent Technology and Engineering. 2019; 8(2):1449-52.

[26] Liow CV, Mah DYS, Malek MA. Modelling of stormpav green pavement system with storm water management model and solidworks flow simulation. 
International Journal of Recent Technology and Engineering. 2019; 8(2):4673-9.

[27] Mah DY, Ngu JO, Taib SN, Mannan MA. Modelling of compartmentalized household stormwater detention system using SWMM5. International Journal of Emerging Trends in Engineering Research. 2020; 8(2):344-9.

[28] Liow CV, Mah DY, Zainol MRRMA. Modelling of stormpav green pavement: inlet and outlet of integrated permeable road and stormwater detention system. International Journal of Civil Engineering and Technology. 2019; 10(2):966-76.

[29] Mah DYS, Ngu JOK, Caroline PD, Malek MA. Catchment size to effective tank volume relationships for individual lot stormwater detention system in Malaysian detached house. International Journal of Advanced Trends in Computer Science and Engineering. 2020; 9(5):8358-63.

[30] Jiang AZ, Mcbean EA. Performance of lot-level low impact development technologies under historical and climate change scenarios. Journal of HydroEnvironment Research. 2021;38:4-13.

[31] Anderson BC, Watt WE, Marsalek J, Ng J, Sneyd B. Feasibility of the application of integrated stormwater management for land-restricted lakeside villages: the case study of Portland, Ontario. Canadian Water Resources Journal. 2008; 33(3):295-306.

[32] Jayakaran AD, Rhodes E, Vogel J. Stormwater management at the lot level: engaging homeowners and business owners to adopt green stormwater infrastructure. In Oxford Research Encyclopedia of Environmental Science. 2021.

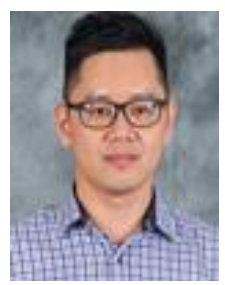

Ir Dr Darrien Yau Seng Mah is an Associate Professor in the Department of Civil Engineering, Faculty of Engineering, Universiti Malaysia Sarawak. He obtained his PhD degree from Universiti Malaysia Sarawak. His research interest is Water Resources Modelling.

Email: ysmah@unimas.my

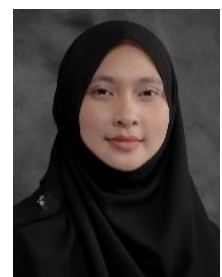

Dr Norazlina Bateni is a senior lecturer with the Department of Civil Engineering, Faculty of Engineering, Universiti Malaysia Sarawak. She obtained her PhD degree from University Malaya. Her research interest is Stormwater Management.

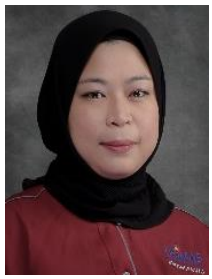

Dr Rosmina Ahmad Bustami is a senior lecturer with the Department of Civil Engineering, Faculty of Engineering, Universiti Malaysia Sarawak. She obtained her PhD degree from University of Southern Australia. Her research interest is Water Sensitive Urban Design.

Email: abrosmina@unimas.my

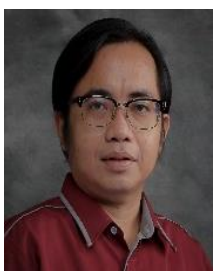

Dr Jethro Henry Adam is a senior lecturer with the Department of Civil Engineering, Faculty of Engineering, Universiti Malaysia Sarawak. His research interest is Sustainable Management of the Urban Environment.

Email: hajethro@unimas.my

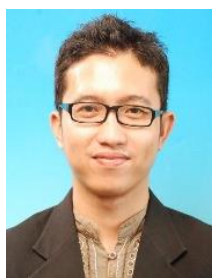

Afdal Haziq bin Mohamad Salehe is the founder and Managing Director of Syarikat Haziq Jaya Pvt Ltd. He obtained his Master of Civil Engineering from Universiti Malaysia Sarawak. His research interest is Civil Engineeringrelated Technology.

Email: afdalhaziqms@gmail.com

Email: bnorazlina@unimas.my 